\title{
Some egg and hatching traits of local ducks, Turkish Pekins and Muscovy ducks in Isparta/Turkey (short communication)
}

\begin{abstract}
The purpose of the research was to study some egg and hatching traits of Boz, Yeşilbaş, Kara ducks (as the local names) in comparison with Turkish Pekin and Muscovy ducks in intensive conditions in Isparta province of Turkey.

Average egg weights of Boz, Yeşilbaş, Kara, Turkish Pekin, Black Muscovy, Black-white Muscovy, White Muscovy ducks were 68.6, 71.5, 71.0, 71.5, 73.3, 76.3, 75.5g; average percentages of fertility were 70.2, 73.0, 54.2, 78.5, 63.4, 33.5, $64.5 \%$, respectively.

Black-white Muscovy ducks had the highest egg weight. Minor differences were found in the values of egg shape index and values of fertility. The percentage of hatchability of fertile eggs and embryo mortality did not differ among genotypes. The weight of day-old bird there were significant differences between the genotypes. A high weight reached Black-White Muscovy ducks with $46.2 \mathrm{~g}$ and the lowest weight were found in Boz genotype with $41.7 \mathrm{~g}$. The results were discussed.
\end{abstract}

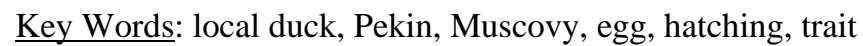

\section{Zusammenfassung}

Titel der Arbeit: Einige Ei- und Bruteigenschaften von einheimischen Entenrassen, Türkischen Pekingund Muscovy-Enten in Isparta/Türkei (Kurzmitteilung)

Zweck dieser Arbeit war, einige Ei- und Bruteigenschaften von Boz, Yeşilbaş, Kara (lokale Namen) Enten im Vergleich zu Türkisch Peking- und Muscovy-Enten in der Isparta Provinz der Türkei zu untersuchen.

Die durchschnittlichen Eigewichte der Rassen Boz, Yeşilbaş, Kara, Türkisch Peking, Schwarz Muscovy, Schwarz-Weiss Muscovy und Weiss Muscovy waren 68,6, 71,5, 71,0, 71,5, 73,3, 76,3, 75,5 g; die durchschnittliche Befruchtungsrate bei diesen Rassen lag bei 70,2, 73,0, 54,2, 78,5, 63,4, 33,5, 64,5 \%. SchwarzWeiss Muscovy Enten hatten die höchsten Eigewichte. Geringe Unterschiede wurden bei dem Merkmal Eiformindex gefunden. Für die Schlupfrate der befruchteten Eier und die Embryomortalität fanden sich keine Unterschiede zwischen den Genotypen $(\mathrm{P}<0,05)$. Die größten Eintagskückengewichte erreichten die BlackWhite Muskovy mit 46,2 g, die niedrigsten die Tiere der Boz Population mit 41,2 g. Die Ergebnisse werden diskutiert.

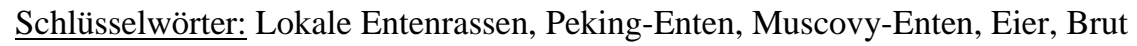

\section{Introduction}

In some regions of Turkey the local duck genotypes have been extensively raised for many years in small family farms. But, there is no information available on characteristics and performances of local duck breeds in Turkey (SELCUK and AKYURT, 1986). We have no statistical data on duck breeding potential in Turkey, it is only known that there are very few small-scale duck farms raising Pekin ducks (TESTIK, 1995).

In Turkey, on this subject, the first development was in 1984 and with Pekin ducks which the number reached 46.000 ducklings (TURKOGLU, 1993). Different duck genotypes are brought by various lines from abroad to Turkey. On the other hand, the 
local duck genotypes, Turkey's animal protein sources, are bred by the rural areas population under the extensive conditions as primitive and innocuous (ISGUZAR and TESTIK, 1999). ISGUZAR et al. (2002) reported about growth, carcass traits and meat quality of local ducks and could prove that these breeds could be important for crossbreed programs.

The purpose of this research was to bring to light of the local duck's some egg and hatching traits, to compare with different duck genotypes.

\section{Material and method}

Research materials consisted of breeder eggs of local duck genotypes (Kara, Yeşilbaş, Boz) which are widespread around Şarkikaraağaç/Isparta province, Turkish Pekin and Turkish Muscovy duck genotypes (black, black-white and white varieties).

The local duck genotypes were determined by ISGUZAR and TESTIK (1999) of Boz, Yeşilbaş, Kara (as the local names) in Isparta region of Turkey. And then, these genotypes (three types of local duck, three types of Muscovy duck and one type Turkish Pekin duck) were bought from the duck farms in Isparta region. The genotypes were 1/3 ratio of male/female, and in hen house there were hay litter on the ground and the long plastic feeder and the water canal of $25 \times 20 \mathrm{~cm}$ for only drinking water under intensive conditions. The genotypes had no artificial nesting-box and they had built the himself natural nesting into the hay litter on the ground. The breeders were only fed with a commercial layer breeding feed (pellets of $16 \%$ protein and $2850 \mathrm{kcal} / \mathrm{kgME}$ ) since appropriate hatching duration and storage conditions were also provided by the laying period. The breeder ducks had have ad libitum feed and water with no grazing, no access to water-pool and no meadow, ect. They were kept under intensive conditions in the hen house. Breeder ducks started to lay and each genotype group's eggs consisted of 30-126, and identified with the different numbers according to each genotype groups and weighted by electronic weight tool before each hatching time. All egg's length and width were measured by scale. The egg shape indexes were calculated by formula that were the egg's width / the egg's length $\mathrm{x} 100$. Thus, egg shapes were determined. The breeder duck's eggs were placed into pre-incubator at ones in the end of two weeks as three different hatching in the spring laying period. The hatching of fertile eggs and the mortality of embryo were determined by the finishing data of hatching and at 14 days of fertility.

Statistical analyses were done with MINITAB for WINDOWS (version 10.5). MstatC was used for the test of significance between groups. The proportional values related with hatching which are fertility $\%$, hatching of fertile egg \% and embryo mortality \% were transformed to angular values for variance analysis.

\section{Results}

Table 1 and 2 show the means of egg weights and egg shape index of genotypes according to hatching times in the same laying period, respectively.

The average egg weights of local ducks, Turkish Pekin and Muscovy ducks were 68.6 to 71.5 g respectively 71.0, the egg weight of the other races lay about these (Table 1 ). General average egg shape indexes was similar at all races 0.75. Only Black-White Muscovy reached 0.76 (Table 2). 
Table 1

Average egg weights in different hatching (g) (Durchschnittliche Eigewichte in unterschiedlichen Brutzeiten (g))

\begin{tabular}{|c|c|c|c|c|c|c|c|c|}
\hline $\begin{array}{l}\text { DUCK } \\
\text { GENOTYPES }\end{array}$ & $\mathrm{n}$ & $\begin{array}{l}(1) \\
\bar{X} \pm S_{\bar{X}}\end{array}$ & $\mathrm{HA}$ & $\begin{array}{l}\text { C H I N G } \\
(2) \\
\bar{X} \pm S_{\bar{X}}\end{array}$ & $\mathrm{n}$ & $\begin{array}{l}(3) \\
\bar{X} \pm S_{\bar{X}}\end{array}$ & $\mathrm{n}$ & $\begin{array}{l}\text { GENERAL } \\
\bar{X} \pm S_{\bar{x}}\end{array}$ \\
\hline$\overline{\mathrm{Boz}}$ & 95 & $70.3 \pm 0.5^{\mathrm{d}}$ & 105 & $67.6 \pm 0.5^{\mathrm{c}}$ & 71 & $67.8 \pm 0.5^{c}$ & 271 & $68.6 \pm 0.3^{\mathrm{d}}$ \\
\hline Yeşilbaş & 126 & $76.3 \pm 0.6^{\mathrm{a}}$ & 115 & $69.2 \pm 0.6^{\mathrm{bc}}$ & 79 & $69.1 \pm 0.8^{c}$ & 320 & $71.5 \pm 2.4^{\mathrm{c}}$ \\
\hline Kara & 76 & $72.2 \pm 0.7^{\mathrm{bcd}}$ & 87 & $70.3 \pm 0.7^{\mathrm{b}}$ & 52 & $70.7 \pm 1.0^{\mathrm{c}}$ & 215 & $71.0 \pm 0.6^{\mathrm{c}}$ \\
\hline Turkish Pekin & 63 & $73.1 \pm 0.6^{\mathrm{bc}}$ & 41 & $70.7 \pm 0.9^{b}$ & 25 & $70.8 \pm 1.2^{c}$ & 129 & $71.5 \pm 0.8^{c}$ \\
\hline Black Muscovy & 31 & $71.1 \pm 1.0^{\mathrm{cd}}$ & 45 & $74.9 \pm 0.6^{\mathrm{a}}$ & 25 & $74.0 \pm 0.7^{\mathrm{b}}$ & 101 & $73.3 \pm 1.2^{\mathrm{b}}$ \\
\hline Black-white Muscovy & 44 & $74.1 \pm 1.3^{\mathrm{ab}}$ & 46 & $77.2 \pm 0.9^{\mathrm{a}}$ & 32 & $77.5 \pm 1.0^{\mathrm{a}}$ & 122 & $76.3 \pm 1.1^{\mathrm{a}}$ \\
\hline White Muscovy & 30 & $71.3 \pm 1.2^{\mathrm{cd}}$ & 39 & $77.2 \pm 1.3^{\mathrm{a}}$ & 24 & $78.0 \pm 1.8^{\mathrm{a}}$ & 93 & $75.5 \pm 2.1^{\mathrm{a}}$ \\
\hline
\end{tabular}

Table 2

Average egg shape indexes in different hatching (Durchschnittlicher Eiformindex bei unterschiedlichen Brutzeiten)

\begin{tabular}{|c|c|c|c|c|c|c|c|c|}
\hline $\begin{array}{l}\text { DUCK } \\
\text { GENOTYPES }\end{array}$ & $\mathrm{n}$ & $\begin{array}{l}(1) \\
\bar{X} \pm S_{\bar{X}}\end{array}$ & $\begin{array}{l}\mathrm{H} \text { A } \\
\mathrm{n}\end{array}$ & $\begin{array}{l}\text { C H I N G } \\
(2) \\
\bar{X} \pm S_{\bar{X}}\end{array}$ & $\mathrm{n}$ & $\begin{array}{l}\text { (3) } \\
\bar{X} \pm S_{\bar{X}}\end{array}$ & $\mathrm{n}$ & $\begin{array}{l}\text { GENERAL } \\
\bar{X} \pm S_{\bar{X}}\end{array}$ \\
\hline $\mathrm{Boz}$ & 95 & $0.77 \pm 0.01^{\mathrm{a}}$ & 105 & $0.74 \pm 0.00^{\mathrm{b}}$ & 71 & $0.75 \pm 0.00^{\mathrm{a}}$ & 271 & $0.75 \pm 0.00^{\mathrm{ab}}$ \\
\hline Yeşilbaş & 126 & $0.78 \pm 0.01^{\mathrm{a}}$ & 115 & $0.73 \pm 0.00^{c}$ & 79 & $0.72 \pm 0.00^{\mathrm{b}}$ & 320 & $0.75 \pm 0.00^{\mathrm{b}}$ \\
\hline Kara & 76 & $0.74 \pm 0.00^{\mathrm{bc}}$ & 87 & $0.75 \pm 0.00^{\mathrm{ab}}$ & 52 & $0.75 \pm 0.00^{\mathrm{a}}$ & 215 & $0.75 \pm 0.00^{\mathrm{b}}$ \\
\hline Turkish Pekin & 63 & $0.76 \pm 0.01^{\mathrm{ab}}$ & 41 & $0.75 \pm 0.00^{\mathrm{ab}}$ & 25 & $0.75 \pm 0.01^{\mathrm{a}}$ & 129 & $0.75 \pm 0.01^{\mathrm{ab}}$ \\
\hline Black Muscovy & 31 & $0.76 \pm 0.01^{\mathrm{ab}}$ & 45 & $0.75 \pm 0.00^{\mathrm{ab}}$ & 25 & $0.75 \pm 0.01^{\mathrm{a}}$ & 101 & $0.75 \pm 0.00^{\mathrm{ab}}$ \\
\hline Black-white Muscovy & 44 & $0.76 \pm 0.01^{\mathrm{ab}}$ & 46 & $0.76 \pm 0.00^{\mathrm{a}}$ & 32 & $0.76 \pm 0.00^{\mathrm{a}}$ & 122 & $0.76 \pm 0.00^{\mathrm{a}}$ \\
\hline White Muscovy & 30 & $0.72 \pm 0.00^{\mathrm{c}}$ & 39 & $0.76 \pm 0.00^{\mathrm{a}}$ & 24 & $0.76 \pm 0.01^{\mathrm{a}}$ & 93 & $0.75 \pm 0.01^{b}$ \\
\hline
\end{tabular}

$\overline{\mathrm{a}, \mathrm{b}}=$ Different letters in the same column show significant difference $(\mathrm{P}<0.05)$.

The Tables 3 to 6 shows the results of hatching traits. The values of fertility in different hatching times at the same laying period (Table 3) show high differences between the genotypes from $33.5 \%$ to $78.5 \%$. The best values reached Turkish Pekin (78.5 \%), and the two local populations Boz (70.2 \%) and Yesilbas (73.0 \%). White Muscovy reached only $33.5 \%$.

Table 3

Average values of fertility in different hatching (\%) (Durchschnittliche Befruchtungsrate bei unterschiedlichen Brutzeiten (\%))

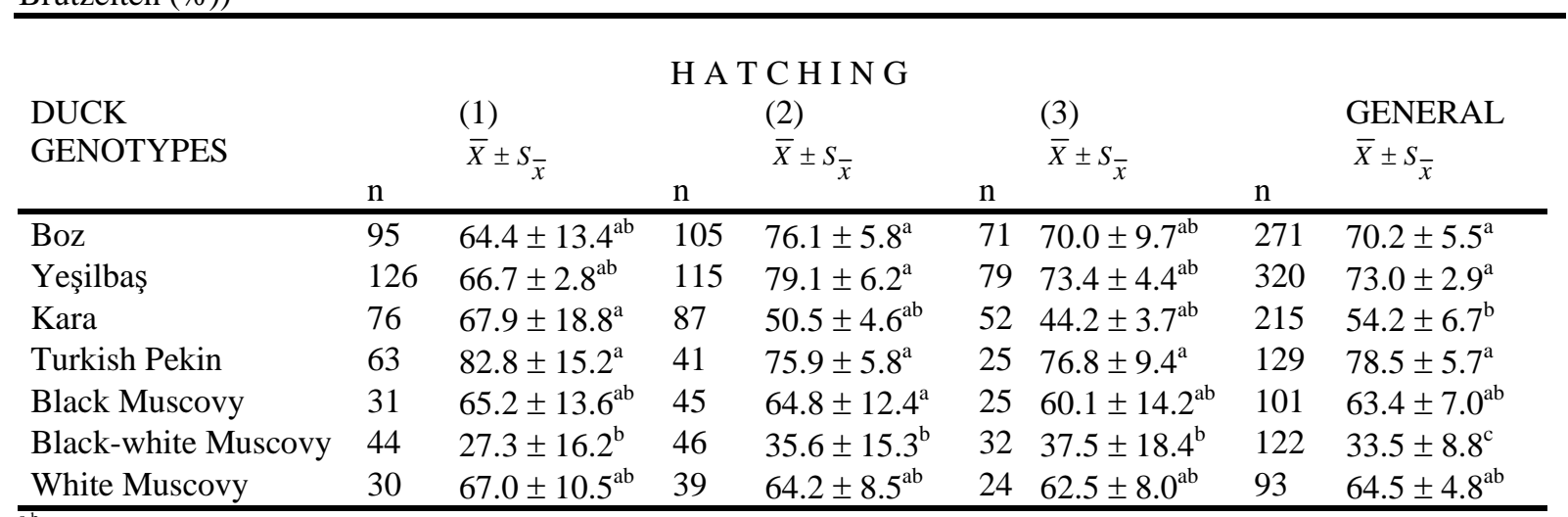

$\overline{\mathrm{a}, \mathrm{b}}=$ Different letters in the same column show significant difference $(\mathrm{P}<0.05)$.

The values of hatchability of fertile eggs and of the embryo mortality (Table 4 and Table 5) show that there were not significant differences $(\mathrm{P}<0.05)$ among genotypes, 
but, there were significant differences for the day-old bird weight among the genotypes. The low and high weights reached Boz and Black-White Muscovy respectively. (Table 6)

Table 4

Average values of the hatchability of fertile eggs in different hatching (\%) (Schlupfrate befruchteter Eier bei unterschiedlichen Brutzeiten (\%))

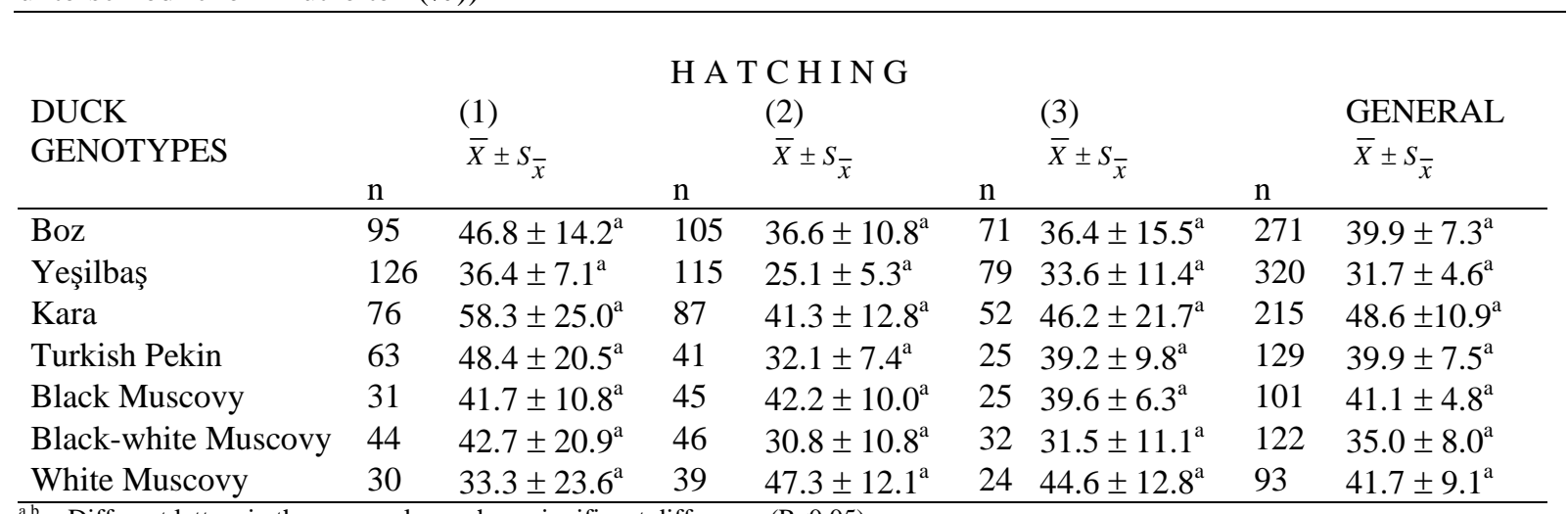

$\overline{\mathrm{a}, \mathrm{b}}=$ Different letters in the same column show significant difference $(\mathrm{P}<0.05)$.

Table 5

Average values of the embryo mortality in different hatching (\%) (Durchschnittliche Embryonenmortalität bei unterschiedlichen Brutzeiten (\%))

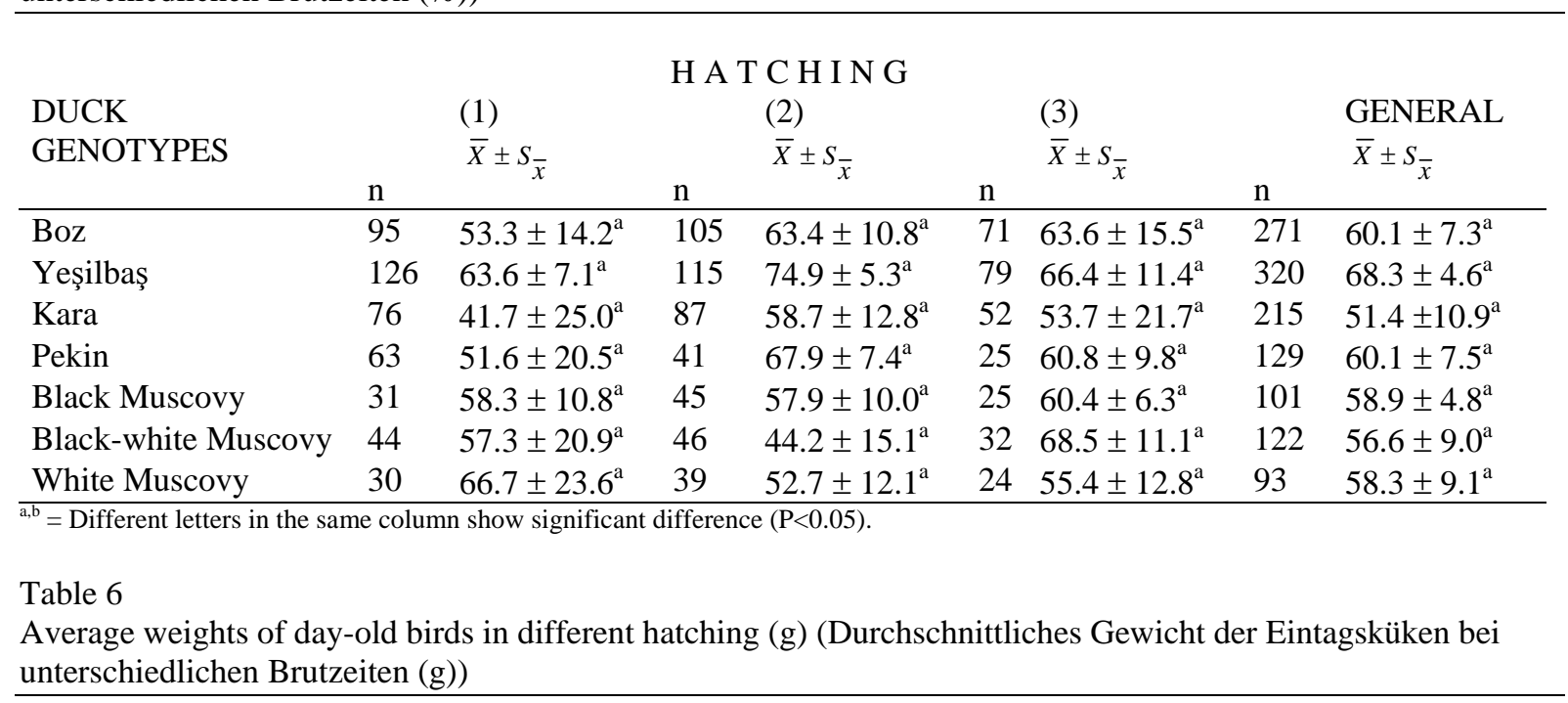

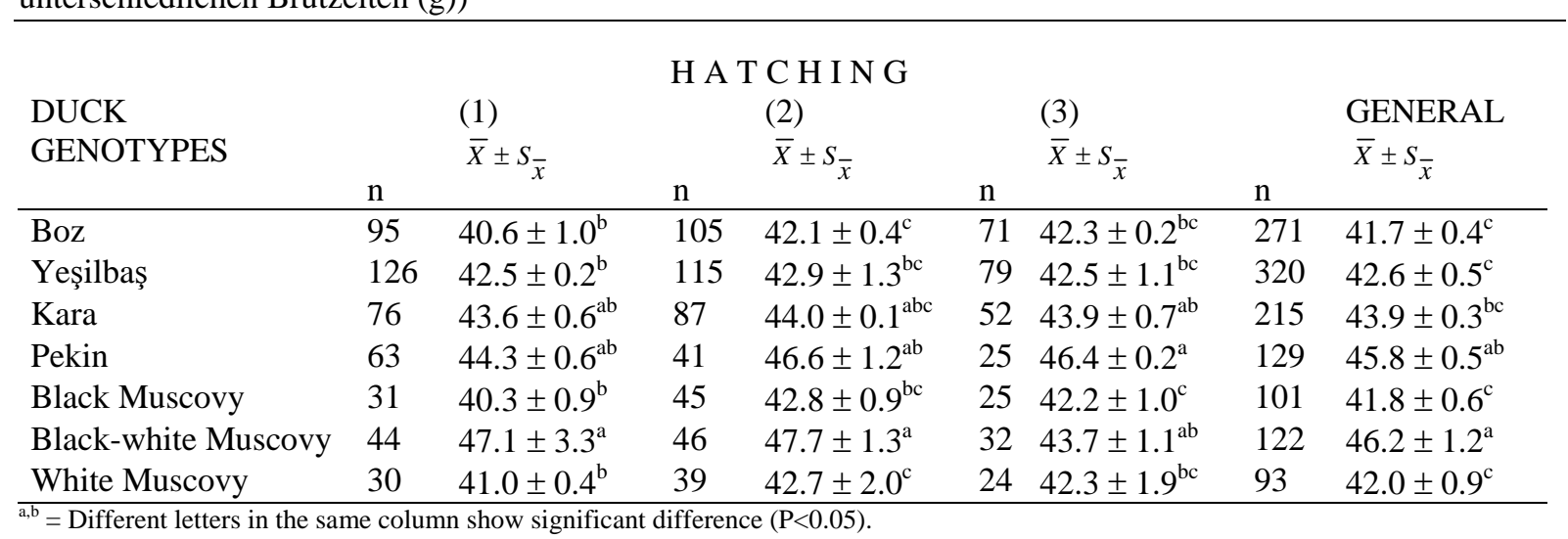

\section{Discussion}

Conservation of genetically different duck races, existing in small populations and threatened with extinction is required for economic, scientific and histological reasons 
(KSIAZKIEWICZ, 2003). Such flocks are being used in the duck to create new breeding or synthetic groups as well as to search for heterosis effects in commercial crossbreeds (ISGUZAR et al., 2002).

The purpose of this study was to compare some reproduction traits of local ducks of different genotypes. In this way, these values of egg traits of local ducks were similar to the results of KARACA et al. (1996) who found Turkish Pekin with $69.9 \mathrm{~g}$ egg weight or TESTIK and SARICA (1991) with 71.5 to $74.2 \mathrm{~g}$. Generally the studies related to egg weight of Pekins ducks in literature show a high variability between 61.5 to 84.4g. ISGUZAR and TESTIK (1999) found in local ducks with extensive conditions lower egg weight's with 54.8 to $64.2 \mathrm{~g}$, other authors similar results. For example Khaki Campell and Desi Ducks with 37.8 to 43.9 g (GAJENDRAN et al., 1990), Shaoxin ducks and Campbel ducks with 51.7 to $64.6 \mathrm{~g}$ (GE et al., 2000). Some authors reported about high egg weight's in Muscovy populations for example with 70.6 g (NIKOLOVA and GERZILOW, 2000) respectively 84.5 g (HARUN et al., 2001). ROMBOLI et al. (1987) found in Black, White and Sepia varieties Muscovy 81.2, and 84.3 and 84.8 g respectively. In this study the results of Boz, Yesilbas and Kara were similar to Turkish Pekin's, but expected lower to Muscovy ducks. The results had shown that there were significant differences among genotypes for egg weight, similarities between local and Pekin ducks and significant differences from those to Muscovy ducks for egg weight. A compare with literature results is difficult because many influences works.

No differences were found in the values of egg shape index in the different hatching in the same laying period.

The results of fertility show that there were significant differences among genotypes. The best values reached Turkish Pekin and the two local races Boz and Yesilbas. Despite the high egg weight Black-White Muskovy obtained the lowest values. The literature described very various values higher and lower than in this investigation. These values were higher to the native ducks having 25.0 to $55.0 \%$ (SELCUK and AKYRUT, 1986) and to local Moscovy ducks having 17.8 to 36.8 \% (HANH et al., 1995). FATTOUH et al. (2003) reported about Muscovy ducks with fertility values of $87.8 \%$.

The values of the hatchability of fertile eggs were similar in the literature (SELCUK and AKYURT, 1986). Other authors reported about higher values (KARAMAN and TESTIK, 1995; FATTOUH et al., 2003). Hatchability fertile eggs just like the values of embryo mortality there were not significant difference between local ducks, Turkish Pekin and Muscovy ducks. The percentage of the fertility, the hatchability of fertile eggs and the embryo mortality were relatively low (Tables 3 to 5). This is due to the fact that the breeder ducks were completely kept indoors without having access to outdoors and only fed with a commercial layer breeding feed since appropriate hatching duration and storage conditions were also provided. The breeder ducks had have no grazing, no meadow, no access to water-pool, no running ect., and they have the fresh drinking water, the clean hay litter and appropriate management in the breeder laying house under the intensive conditions.

The weight of day-old birds were similar to Pekin ducks with 45.0.to $59.0 \mathrm{~g}$ and $45.0 \mathrm{~g}$ respectively (KNIZETOVA et al., 1992; SHAHIN et al., 2000) but lower than results of KARAMAN and TESTIK with 47.8 to $55.8 \mathrm{~g}$. Between genotypes in this investigation there were significant differences between genotypes. High weight 
reached Black-White Muscovy ducks and the lowest were found in Boz genotype. There is certainly a positive correlation to the egg weight (KARAMAN and TESTIK, 1995). Egg and hatching traits are strongly influenced by environment therefore are compares with the literature heavily.

The aim of this study was to compare some reproductive traits of different Turkish local and other duck populations. The proved performances make possible a better judgment of this genotypes, hers conservation, further development or to create new commercial crossbreds.

\section{References}

FATTOUH, M. H.; TAG EL DIN, T. H.; GAD, H. A. M.; KHALIFAH, M. M.:

Effect of force moulting method on some post moulting traits in ducks 2- Fertility and hatchability. $2^{\text {nd }}$ World Waterfowl Conference, 7- 9 October, Alexandria/Egypt (2003)

GAJENDRAN, K.; KOTHANDARAMAN, P.; SHERIFF, FR.:

Performance of Khaki Campbell and desi ducks under intensive system of rearing in maritime monsoon type of climate. Cheiron 19 (1992) 5, 213-219; Rec. 386 of 408-CAB Abst., 1990

GE, S.F.; ZHAO, R.Q.; CHEN, J.; LU, L.Z.; SHEN, J.D.:

Comparative study on the laying performances of Shaoxin Duck and Khaki-Campbell Duck. C Chinese Journal of Animal Science 36 (2000) 5, 22-23

HANH, D.T.; HAI, L.TH.; HUNG, D.S.; TINH, N.H.: Improving the productivity of local muskovy duck and initial production experiment of Mulard in Vietnam. $10^{\text {th }}$ European Symposium on waterfowl (1995) proceeding, 31

HARUN, M.A.S.; VEENEKLAAS, R.J.; VISSER, G.H.; KAMPEN, M VAN.; VAN KAMPEN, M.:

Artificial incubation of Muscovy duck eggs: why some eggs hatch and others do not. Poultry Science 80 ((2001) 2, 219-224

ISGUZAR, E.; TESTIK, A.:

An investigation on local genotypes of waterfowl in Isparta province of Turkey. $12^{\text {th }}$ European Symp. on waterfowl, (1999), proceeding, 51-56

ISGUZAR, E.; KOCAK, C.; PINGEL, H.:

Growth, carcass traits and meat quality of different local ducks and Turkish Pekins. Arch. Tierz., Dummerstorf 45 (2002) 4, 413-418

KARACA, O.; OKUT, H.; ALTIN, T.:

The estimation on some parameters of Pekin ducks's egg productions. I. National Congrees of Zootecnical, Antalya/Turkey (1996)

KARAMAN, M.; TESTIK, A.:

The study of effects on hatching and growth performances of Pekin ducks's different weight eggs. International congrees of poultry husbandry, Istambul (1995) proceeding, 485-492,

KNIZETOVA, H.; HYANEK, J.; CERVENY, J.: Egg size and post-hatch growth of Pekin duck. Arch. Geflügelkunde 56 (1992) 3, 128-131

KSIAZKIEWICZ, J. M.:

Comparison of reproduction and carcass traits in light type of ducks of four conservative flocks over eight generations. Arch. Tierz., Dummerstorf 46 (2003) 4, 377-389

NIKOLOVA, M.; GERZILOV, V.:

Study on egg productivity of Muscovy ducks (Cairina moschata). II. Morphological characteristic. Zhivotnov"dni Nauki 37 (2000) 4, 13-16; Rec. 173 of 758 in CAB Abstracts 2000/08-2002/07.

ROMBOLI, I.; GIULOTTI, L.; AVANZI, CF.:

Reproductive activity of some varieties of Muscovy duck in successive egg laying cycles. Rivista di Avicoltura, 56 (1987) 12, 73-75, Rec. 201 of 408-CAB Abst. (1987-1989)

SELCUK, E.; AKYURT, I.:

Duck husbandry. The Ministry of Agriculture and Forestry, publication no: 8, Ankara/Turkey (1986)

SHAHIN, K. A.; SHEMES, A. R.; ABDALLAH, O. Y.; SALEH, K.:

Effects of genetic control of subcutaneous fat deposition via using restricted selection indexes on live performance and carcass characteristics of Pekin ducks. Arch. Tierz., Dummerstorf. 43 (2000) 1, 69-77

TESTIK, A.:

The situation of ducks and geese production in Turkey. $10^{\text {th }}$ European Symp. on waterfowl (1995) proceeding, 43-45

TESTIK, A.; SARICA, M.: 
An investigation on the egg quality traits of Pekin ducks. International congrees of poultry husbandry, Istambul (1991) proceeding, 85-91

TURKOGLU, M.:

The investigation on improving of hatching performance of Pekin ducks in Turkey. Ankara UniversityAgriculture Faculty, publication no: 1288, Ankara/Turkey (1993)

Received: 2003-04-07

Accepted: 2004-12-03

Author's address

Dr. ERGÜL İŞGÜZAR

Süleyman Demirel University,

Faculty of Agriculture,

Depart. of Animal Breeding,

Isparta-Turkey 